SINET: Ethiop. J. Sci., 25(2):263-274, 2002

\title{
THE CHEMICAL COMPOSITION OF THE EFFLUENT FROM AWASSA TEXTILE FACTORY AND ITS EFFECTS ON AQUATIC BIOTA
}

\author{
Zinabu Gebre-Mariam and Zerihun Desta \\ Faculty of Natural Sciences, Debub University, PO Box 5 \\ Awassa, Ethiopia, E-mail: zgebremariam@hotmail.com
}

\begin{abstract}
The chemical composition of the effluent from the Awassa textile factory was quantified and its effects on chlorophyll-a concentration and fish fry were examined. The effluent contained high concentrations of toxic heavy metals, and concentrations of about $70 \%$ of all the elements measured were higher (by 10 to 100 times) in effluent treated in ponds (biological lagoons) than straight from the factory, presumably due to concentration by evaporation. Chlorophylla concentration in lake water samples containing $10 \%$ and $20 \%$ textile effluent from the ponds increased by 5 to $1400 \%$ and 7 to $4000 \%$, respectively, whereas the changes in the control were $-24 \%$ to $433 \%$. About $18 \%$ and $53 \%$ of the fish fry died within $12 \mathrm{hr}$ in $10 \%$ and $20 \%$ pond effluent in lake water, respectively. The highest mean mortality level was about $64 \%$ in the $20 \%$ effluent treatment at $24 \mathrm{hr}$. It was concluded that the effluent treatment ponds of the factory do not efficiently reduce the chemicals in the discharge. The observed effects of the "treated effluent" on phytoplankton biomass and fish fry indicate the undesirable effects the effluent will have on Lake Awassa. It is recommended that an alternate waste disposal system for the textile factory be set up, with regular monitoring of its effectiveness, so as to avoid undesirable long-term changes to the lake.
\end{abstract}

\section{Key words/phrases: Chemical composition, chlorophyll-a, fish fry, effluent, textile factory}

\section{INTRODUCTION}

Accelerated water quality change due to industrial pollution is one of the major environmental concerns throughout the world. Industrial effluents and domestic sewage contribute large quantities of nutrients and toxic substances that have a number of adverse effects on the water bodies and the biota (Chhonkar et al., 2000 and references cited therein). Although Ethiopia does not have the industry that flourishes in the developed countries and pollutants are not produced in large quantities, some rivers that flow into certain of the Ethiopian lakes carry discharge from factories 
and domestic sources (Zinabu Gebre-Mariam and Elias Dadebo, 1989; Zinabu Gebre-Mariam, 1998).

The Awassa textile factory is one of the factories operating in the vicinity of Lake Awassa, and it discharges about $1200 \mathrm{~m}^{3}$ of liquid waste every day into the nearby Shallo swamp (Zerihun Desta, 1997). The effluent from the textile factory is routed by way of some treatment ponds (biological lagoons) that are expected to reduce the amount of chemical discharge. The effluent from the ponds, which is assumed to be "treated effluent", discharges into the Shallo swamp when the ponds fill up or through leakage. The swamp is the source of River Tikur wuha, the only river that flows into Lake Awassa, and the effluent released into the swamp eventually ends up in this closed lake (that has no surface outflow). Removal of the chemicals in the waste water through the biological filtration of the lagoons is required to prevent advancement of nutrient enrichment and excessive algal production (eutrophication). However, the effectiveness of the treatment ponds of the Awassa textile factory is not known. Moreover, no information is available on the chemical composition of the effluent and its possible effects on the biota of Lake Awassa. Such information is important with respect to the environmental protection and resource management of the lake.

The objective of this study was to determine the chemical composition of the effluent of the Awassa textile factory and examine its effects on phytoplankton biomass and fish fry.

\section{MATERIALS AND METHODS}

\section{Sample collection}

Water samples for our experiments were collected from the surface of Lake Awassa $\left(6^{\circ} 33^{\prime}-7^{\circ} 33^{\prime} \mathrm{N}\right.$ and $\left.30^{\circ} 22^{\prime}-38^{\circ} 29^{\prime} \mathrm{E}\right)$ described in Zinabu GebreMariam and Taylor (1989) during the study period October 1997 to June 1999. Samples were collected at an offshore sampling station using acidwashed 2-L polyethylene bottles and were transported to the laboratory in dark coolers containing lake water to maintain in situ temperature.

A beach seine was used to collect tilapia (Oreochromis niloticus) fry from the lake shallows. Open coolers and plastic buckets containing lake water were used to transport these fry from the lake to the laboratory. This usually took less than fifteen minutes. 
Effluent samples from the Awassa textile factory were collected from two sites by using acid-washed 2-L polyethylene bottles. Samples were taken directly from the factory outlet (the point where the effluent from the factory is released into the first treatment pond) and from the point where the effluent from the last treatment pond goes into the swamp. These represent the "untreated" and "treated" effluent, respectively. Samples collected in this way were transported to the laboratory in a dark cooler, and were only used for the fish fry and chlorophyll-a experiments.

Effluent samples for chemical analyses were collected from the two sites mentioned above in November 1995 and March 1996 with 2-L acid washed polyethylene bottles. Prior to sampling the bottles were cleaned by incubating them with 10\% (v/v) Nitric acid (Analytical, Merck) solution for $48 \mathrm{hr}$ in a hot water bath, and were then washed and rinsed with distilled and de-ionized water. They were finally thoroughly rinsed with the effluent from the sampling sites before sampling. The effluent samples were returned to the laboratory in dark boxes containing lake water that maintained in situ temperature. Samples for nutrient analyses were filtered through Whatman GF/C glass-fiber filters and stored in polyethylene bottles at temperatures close to $4^{\circ} \mathrm{C}$ until they were analyzed. Samples for analyses of heavy metals and other trace elements were not filtered but stored at temperatures close to $4^{\circ} \mathrm{C}$ until they were sent by air to the Institute of Geography and Earth Sciences, University of Wales, Aberystwyth, U.K. Samples were analyzed within four to six weeks of collection.

\section{Chemical analyses}

Concentrations of 59 elements (heavy metals and other trace elements) were determined by Inductively Coupled Plasma Mass spectrometry (ICPMS) using a VG Plasma Quad II+ with a modified interface. The methods employed were essentially those of Pearce (1992). Bicarbonate and carbonate were determined by titrating unfiltered water samples with standard solution of Hydrochloric acid (Analytical, Merck) to $\mathrm{pH} 4.5$ (Golterman et al., 1978). Nitrate-nitrogen was measured as nitrite by the cadmium reduction method (Golterman et al., 1978). Silica was determined as its molybdate complex as outlined by Wetzel and Likens (1979).

\section{Fish fry experiments}

These were carried out in $5 \mathrm{~L}$ glass aquaria, each treatment in duplicate. The following treatments were used: $20 \%$ and $10 \%$ of the final pond effluent (which we have designated as "treated effluent" for convenience) added to lake water, and a control blank of untreated lake water (BLW). We used 10 and $20 \%$ effluent dilutions, because preliminary tests showed that concentrations 
less than $10 \%$ either showed very little effect or required very long incubation periods before notable changes were observed.

After the effluent was thoroughly mixed with the lake water to make sure of uniform distribution and aeration, equal number of fish fry, usually not more than 10, and of similar size were put into each aquarium. Fry mortality was recorded every $6 \mathrm{hr}$. Most experiments lasted for $48 \mathrm{hrs}$ and were carried out in a laboratory with ambient light and temperature conditions (Zinabu Gebre-Mariam, 1994).

\section{Chlorophyll-a experiments}

To study the impact of the effluent on chlorophyll-a concentration (phytoplankton biomass), $500 \mathrm{ml}$ of water from each treatment prepared for the fish fry experiments, were put in 1-litre glass Erlenmeyer flasks and were incubated in the laboratory for 7 days under light condition that imitated the sub-surface water environment and was found to be optimum for other similar studies (Zinabu Gebre-Mariam, 1994). At the beginning and end of the incubation period chlorophyll-a was estimated spectrophotometrically after filtering $200 \mathrm{ml}$ of water through Whatman GF/C glass-fiber filters and extracting the filters in cold $90 \%$ methanol overnight in the dark. The abbreviated formula of Talling and Driver (1963) was used to calculate the concentration of chlorophyll-a. No correction was made for degradation products.

\section{RESULTS AND DISCUSSION}

\section{Chemical composition of the effluent}

Concentrations of most (about $70 \%$ ) of the elements were higher in the treated effluent samples than in the untreated samples (Table 1). Samples from untreated effluent contained high concentrations of toxic heavy metals like $20 \mu \mathrm{g} \mathrm{l}^{-1}$ of Selenium (Se), $11 \mu \mathrm{g} \mathrm{l}^{-1}$ of Arsenic (As) and $3.8 \mu \mathrm{g} \mathrm{l}^{-1}$ of Mercury $(\mathrm{Hg})$. Concentrations of these and some of the rest of the trace metals in the treated effluent samples were sometimes 10 to 100 times higher than their concentrations in the untreated samples. This is very intriguing given that the purpose of the treatment pond (biological lagoons) is to reduce the concentrations of the metals. The treatment pond seems to be concentrating the effluent, possibly through evaporation, and sending it into the Shallo swamp. Most of the levels of the heavy metals in the treated effluent are much higher than the maximum permissible level (MPL) in drinking water and/or international average values for freshwaters (unpublished data). We do not intend to judge the quality of

the effluent based on MPL or other international standards set for drinking 
water, but since the effluent that is discharged into Shallo swamp ends up in River Tikur wuha and eventually in Lake Awassa, evaluation of the toxic substances in the effluent with reference to normally-accepted values becomes necessary. While the ultimate effects of the chemicals in the effluent on the lake and the river will not be felt for some time to come, the immediate potential health hazard cannot be excluded as many people use water from the swamp and the river for a number of domestic purposes including consumption by humans and cattle. Moreover, given that such high concentrations of trace metals eventually end up in Lake Awassa and trace metals are not usually eliminated from aquatic systems by any known means (Forstner and Wittmann, 1983), it is evident that the lake is facing a very serious threat of contamination.

Table 1. Concentrations of heavy metals and related trace elements in untreated and treated samples of effluent from Awassa textile factory. Values are mean concentrations $\left(\mu \mathrm{g} \mathrm{l}^{-1}\right)$ for samples taken in Nov-95 and March-96. Heavy metals commonly known to be very toxic are shown in bold.

\begin{tabular}{|c|c|c|c|c|c|c|c|}
\hline Elements & Untreated & Treated & $\%$ Change & Elements & Untreated & Treated & $\%$ Change \\
\hline Ag & 0.09 & 0.11 & 25.6 & Mn & 4.19 & 13.16 & 213.9 \\
\hline As & 9.98 & 43.19 & 332.8 & Mo & 6.91 & 5.68 & -17.8 \\
\hline $\mathbf{A u}$ & 0.18 & 0.06 & -67.9 & $\mathrm{Nb}$ & 0.16 & 0.56 & 261.9 \\
\hline Ba & 12.50 & 9.34 & -25.2 & $\mathrm{Nd}$ & 1.41 & 3.29 & 133.1 \\
\hline $\mathrm{Be}$ & 0.99 & 4.73 & 377.8 & $\mathrm{Ni}$ & 1.75 & 3.34 & 90.6 \\
\hline $\mathrm{Bi}$ & 0.01 & 3.22 & 32082.7 & $\mathrm{~Pb}$ & 1.39 & 7.53 & 440.9 \\
\hline $\mathrm{Br}$ & 461.23 & 533.70 & 15.7 & $\operatorname{Pr}$ & 0.06 & 0.63 & 883.4 \\
\hline $\mathrm{Cd}$ & 1.58 & 1.22 & -22.7 & $\mathrm{Rb}$ & 58.36 & 49.38 & -15.4 \\
\hline $\mathrm{Ce}$ & 0.53 & 3.10 & 490.1 & $\mathrm{Sb}$ & 1.63 & 15.05 & 824.3 \\
\hline Co & 0.27 & 0.28 & 2.4 & Sc & 35.49 & 37.47 & 5.6 \\
\hline $\mathrm{Cr}$ & 19.84 & 42.58 & 114.6 & Se & 20.31 & 5.44 & -73.2 \\
\hline Cs & 0.26 & 0.14 & -43.4 & $\mathrm{Sm}$ & 0.69 & 0.67 & -3.6 \\
\hline $\mathrm{Cu}$ & 53.73 & 52.53 & -2.2 & Sn & 0.76 & 0.02 & -97.0 \\
\hline Dy & 0.03 & 0.47 & 1318.2 & $\mathrm{Sr}$ & 90.13 & 87.12 & -3.3 \\
\hline $\mathrm{Er}$ & 0.18 & 0.27 & 49.2 & $\mathrm{Ta}$ & 0.32 & 0.05 & -83.4 \\
\hline $\mathrm{Eu}$ & 0.02 & 0.14 & 746.7 & $\mathrm{~Tb}$ & 0.07 & 0.14 & 98.6 \\
\hline $\mathbf{F e}$ & 131.89 & 75.77 & -42.6 & $\mathrm{Te}$ & 2.54 & 1.73 & -31.9 \\
\hline $\mathrm{Ga}$ & 7.89 & 10.75 & 36.4 & $\mathrm{Th}$ & 0.10 & 0.06 & -34.3 \\
\hline $\mathrm{Gd}$ & 0.21 & 0.74 & 249.5 & $\mathrm{Ti}$ & 33.46 & 38.28 & 14.4 \\
\hline Hf & 0.04 & 0.07 & 61.9 & $\mathrm{Tl}$ & 0.24 & 0.47 & 95.4 \\
\hline $\mathrm{Hg}$ & 3.77 & 5.10 & 35.1 & $\mathrm{Tm}$ & 0.05 & 0.13 & 182.4 \\
\hline Ho & 0.04 & 0.09 & 112.2 & $\mathrm{U}$ & 0.13 & 0.26 & 109.2 \\
\hline $\mathrm{I}$ & 11.89 & 15.25 & 28.3 & $\mathbf{V}$ & 4.42 & 4.79 & 8.4 \\
\hline In & 0.08 & 0.13 & 70.0 & W & 0.55 & 1.26 & 131.1 \\
\hline $\mathrm{La}$ & 0.15 & 1.90 & 1139.3 & $\mathrm{Y}$ & 0.44 & 2.88 & 558.2 \\
\hline $\mathrm{Li}$ & 157.07 & 77.32 & -50.8 & $\mathrm{Yb}$ & 0.14 & 0.29 & 109.3 \\
\hline \multirow[t]{2}{*}{$\mathrm{Lu}$} & 0.04 & 0.03 & -35.1 & $\mathrm{Zn}$ & 85.95 & 57.16 & -33.5 \\
\hline & & & & $\mathrm{Zr}$ & 0.29 & 3.44 & 1107.0 \\
\hline
\end{tabular}


About $45 \%$ of the major ions seemed to be more concentrated in the treated effluent than in the untreated effluent samples (Table 2). The most noticeable differences were in bicarbonate and nitrate. The increase in bicarbonate concentrations in the treated effluent may be associated with the decrease in the concentration of carbonate. The $\mathrm{pH}$ values of the untreated and treated effluent were 12.68 and 9.91, respectively, and this decrease in the $\mathrm{pH}$ (which could be the result of some decomposition activity in the pond) may be associated with the changes in carbonate and bicarbonate ratios. Although we were not able to determine concentrations of ammonia and phosphate, it is very likely that their concentrations would have been much higher than the nutrients presented in Table 2. The effluent samples had the pungent smell of ammonia that smelled almost like urine from cattle, and we suspect a high concentration of ammonia. The effect of the effluent on phytoplankton biomass (see below) could be partly due to the high concentrations of these ions and major nutrients, the concentrations of which are much higher than their concentrations in Lake Awassa (Demeke Kifle and Amaha Belay, 1990; Elizabeth Kebede and Amha Belay, 1990; Zinabu Gebre-Mariam, 1988; Zinabu Gebre-Mariam et al., 2002; Zinabu Gebre-Mariam and Taylor, 1989; Zinabu Gebre-Mariam, 2002 and references cited therein). It is well known that the phosphate ion is the most important pollutant leading to lake eutrophication so it is unfortunate that we were not able to measure it. However, as the factory is handling organic matter there must be a lot of phosphate in the effluent.

Table 2. Concentrations $\left(\mathrm{mg} \mathrm{l}^{-1}\right)$ of some major ions and plant nutrients in treated and untreated samples of effluent from Awassa textile factory.

\begin{tabular}{cccc}
\hline Elements & Untreated & Treated & Difference (\%) \\
\hline $\mathrm{Ca}$ & 24.5 & 17.0 & -30.6 \\
$\mathrm{Cl}$ & 49.8 & 57.9 & 16.4 \\
$\mathrm{CO}_{3}$ & 1428.0 & 960.0 & -32.8 \\
$\mathrm{~F}$ & 3.8 & 3.4 & -9.5 \\
$\mathrm{HCO}$ & 0.1 & 1153.0 & 1152900.0 \\
$\mathrm{~K}$ & 52.3 & 44.5 & -15.0 \\
$\mathrm{Mg}$ & 5.7 & 3.5 & -38.9 \\
$\mathrm{Na}$ & 1347.8 & 1164.5 & -13.6 \\
$\mathrm{NO}_{3}$ & 5.2 & 31.0 & 495.4 \\
$\mathrm{SiO}_{2}$ & 88.0 & 94.0 & 6.8 \\
$\mathrm{SO}_{4}$ & 34.8 & 56.0 & 60.6 \\
\hline
\end{tabular}




\section{Effects of effluent on phytoplankton biomass}

Initial phytoplankton biomass, measured in terms of chlorophyll-a concentrations, did not show marked difference among the three treatments $(10 \%$ and $20 \%$ pond effluent and blank lake water). The mean initial chlorophyll-a concentrations for the three treatments ranged from 17.7 to $20.4 \mu \mathrm{g} \mathrm{l}^{-1}$ with the highest value for blank lake water (BLW) and the lowest for the $20 \%$ effluent sample (Fig. 1). The slight differences observed between the effluent treatments and the control (BLW) are due to the dilution effect.

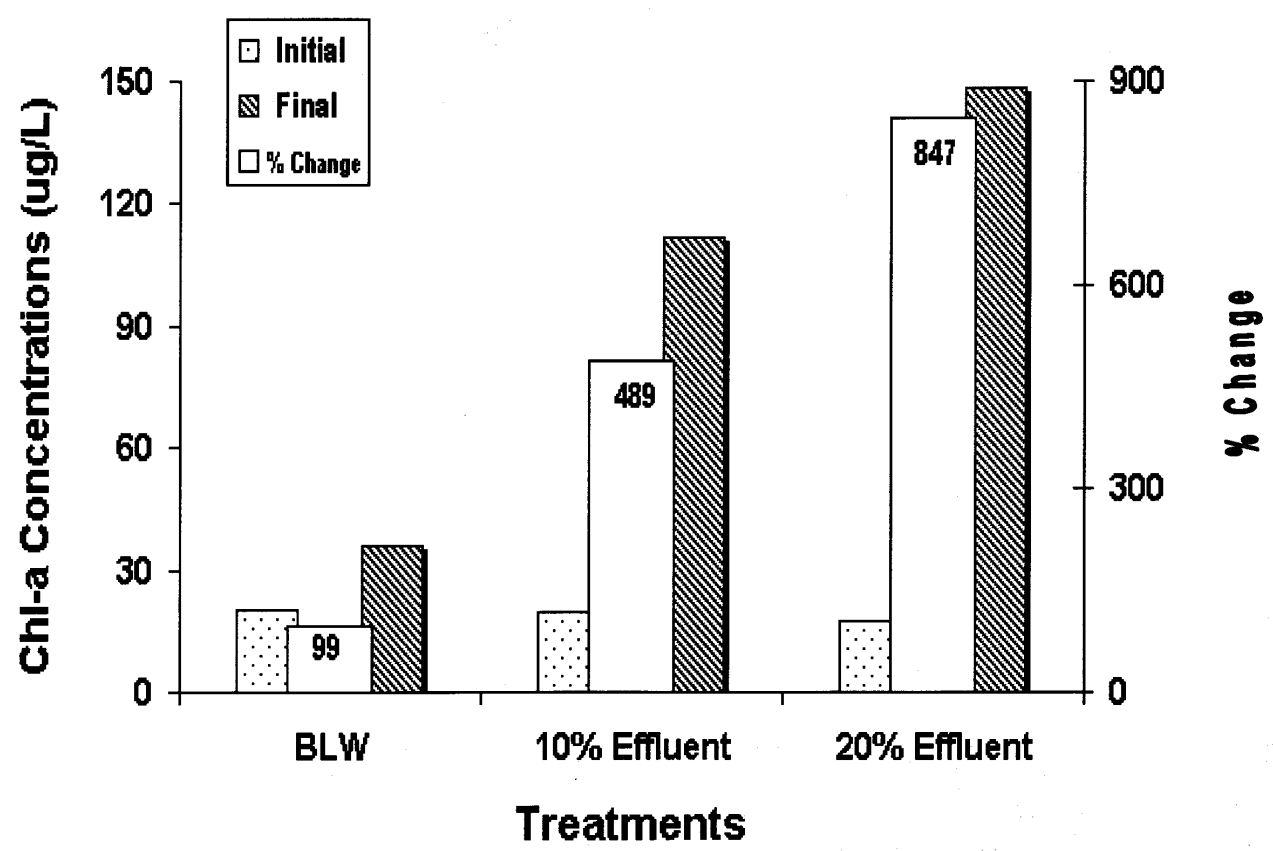

Fig. 1. Initial and final concentrations $\left(\mu \mathrm{g}^{\left.\mathbf{l}^{-1}\right)}\right.$ of chlorophyll-a, and $\%$ changes in different treatments of effluent from Awassa textile factory. Values are means of results from 12 experiments.

The final mean chlorophyll-a concentrations in the three treatments (BLW, $10 \%$ and $20 \%$ effluent) were $35.8,111.8$ and $148.6 \mu \mathrm{g} \mathrm{l}^{-1}$, respectively; and the respective mean percent changes in the three treatments were 98.6, 489 and $847 \%$ (Fig. 1). The final chlorophyll-a concentration in samples containing $10 \%$ and $20 \%$ treated effluent (textile effluent from the pond) increased by 4.89 to $1400 \%$ and 6.92 to $4000 \%$, respectively, where as the changes in the control ranged from $-24 \%$ to $433 \%$ (Table 3 ). The changes in the chlorophyll-a concentrations in the treatments with effluent are presumably due to the high concentrations of plant nutrients in the effluent from the textile factory, and it is apparent that the effluent from the Awassa 
textile factory, which ends up in the Lake Awassa, will bring about eutrophication to the lake. The changes in the final chlorophyll-a concentrations in the control samples were certainly due to bottle effects, which commonly occur in samples incubated in containers for such a long time (Zinabu Gebre-Mariam, 1988). Even if one assumed that similar kind of bottling effect occurred in the treatments that contained the textile effluent, the changes in the chlorophyll-a concentrations in the effluent treatments were by far too high to be due to a bottling effect alone.

Table 3. Initial and final concentrations $\left(\mu \mathrm{g}^{1-1}\right)$ and $\%$ changes of chlorophyll-a in different treatments of effluent from Awassa textile factory during the study period.

\begin{tabular}{|c|c|c|c|c|c|c|c|c|c|}
\hline \multirow{2}{*}{ Date } & \multicolumn{3}{|c|}{ Blank lake water } & \multicolumn{3}{|c|}{$10 \%$ Effluent } & \multicolumn{3}{|c|}{$20 \%$ Effluent } \\
\hline & Initial & Final & $\%$ Change & Initial & Final & $\%$ Change & Initial & Final & $\%$ Change \\
\hline 2-Sep-97 & 36.49 & 55.78 & 52.86 & 29.72 & 100.61 & 238.53 & 30.29 & 215.28 & 610.73 \\
\hline 16-Oct-97 & 12.93 & 67.42 & 421.42 & 12.93 & 108.00 & 735.27 & 12.93 & 243.00 & 1779.35 \\
\hline 4-Nov-97 & 15.64 & 83.40 & 433.25 & 15.64 & 211.11 & 1249.81 & 14.60 & 96.96 & 564.11 \\
\hline 18-Nov-97 & 14.60 & 11.45 & -21.58 & 15.64 & 60.45 & 286.51 & 14.60 & 31.95 & 118.84 \\
\hline 12-Dec-97 & 22.90 & 0.00 & -100.00 & 22.20 & 13.55 & -38.96 & 18.85 & 13.20 & -29.97 \\
\hline 31-Dec-97 & 26.10 & 19.80 & -24.14 & 23.60 & 359.63 & 1423.86 & 18.80 & 148.00 & 687.23 \\
\hline 14-Jan-98 & 19.88 & 36.15 & 81.84 & 19.50 & 177.90 & 812.31 & 12.50 & 36.85 & 194.80 \\
\hline 12-Feb-98 & 24.65 & 19.50 & -20.89 & 23.51 & 64.65 & 174.99 & 20.35 & 54.20 & 166.34 \\
\hline 27-Feb-98 & 16.35 & 45.90 & 180.73 & 18.80 & 91.75 & 388.03 & 19.50 & 20.85 & 6.92 \\
\hline 11-Mar-98 & 15.75 & 26.40 & 67.62 & 16.00 & 89.00 & 456.25 & 18.80 & 69.50 & 269.68 \\
\hline 30-Jul-98 & 25.86 & 44.62 & 72.54 & 19.18 & 54.21 & 182.64 & 12.93 & 560.17 & 4232.33 \\
\hline 8-Aug-98 & 13.90 & 19.40 & 39.57 & 19.00 & 19.93 & 4.89 & 17.60 & 293.00 & 1564.77 \\
\hline
\end{tabular}

The changes in chlorophyll-a concentrations in the $20 \%$ effluent treatment were almost always lower than those in the $10 \%$ treatments, except in the samples taken in September, October, July and August (Table 3). A possible explanation for this scenario is that the textile effluent boosts phytoplankton growth at lower concentrations but becomes inhibitory as its concentration increases beyond a given point probably as a result of toxicity. Otherwise, the increase in the chlorophyll-a concentrations should always have been higher in the $20 \%$ treatments than in the $10 \%$. The four occasions during which the $20 \%$ effluent treatments had higher concentrations than the $10 \%$ treatment were very likely associated with heavy rains. Therefore, it is possible that the rains diluted the effluent in the treatment pond and the $20 \%$ effluent treatment was much more dilute during these sampling periods than the other sampling periods. This may 
have led the $20 \%$ effluent treatment to behave like the $10 \%$ treatment from other sampling periods. The fact that the chlorophyll-a concentrations in the $10 \%$ effluent treatments were much lower during these four sampling periods (during the rainy seasons) than the rest of the study period (Table 3) further substantiates our argument. To clarify this problem, further studies involving serial dilution experiments of effluent treatments need to be carried out to reveal the exact concentrations at which the effluent inhibits phytoplankton growth. Needless to mention that from the point of view of the impacts the effluent will have on the lake, either boosting or inhibiting phytoplankton growth is detrimental to the health of the lake and its biota.

Notwithstanding what has been said in the foregoing section, the differences we observed in the effect of the effluent on the chlorophyll-a concentrations could further be confounded by differences in the intensity of activities in the textile factory and types of chemicals used over the year. We were not able to obtain information as to the periodicity of the activities and the type of the chemicals used at different times of the year, but our speculation is that the activities of the factory vary throughout the year.

What awaits further study is the real meaning of the high values of the chlorophyll-a concentrations in the effluent treatments. Were they due to increase in the biomass of certain groups of phytoplankton or is just a response of the whole phytoplankton assemblage? If such selection occurs and the textile effluent favors a phytoplankton group producing toxic substances, the effect of the effluent on the lake would be more catastrophic. On the other hand, phytoplankton group that grows copiously in the textile effluent could also be adapted to grow in the treatment ponds and the swamp and thereby reduce nutrient loading.

\section{Effects of effluent on fish fry}

Eighteen and 53\% of the fish fry in 10 and $20 \%$ effluent treatment, respectively, died within $12 \mathrm{hr}$. Although there were times when 100\% death was observed in $20 \%$ effluent treatments the mean percentage death in this treatment was about $64 \%$, and usually occurred by $24 \mathrm{hr}$ (Fig. 2). The percentage death in the $10 \%$ treatment was only $23 \%$ at $24 \mathrm{hr}$. A preliminary test showed that the undiluted effluent killed fish fry in less than 15 minutes and adult fish died in much shorter time than the fry. This suggests that the effluent from Awassa textile factory has toxic effects on fish that becomes more severe with increasing effluent concentration.

The fact that some fry did not die in $48 \mathrm{hr}$ suggests that fish fry can sometimes tolerate the impact of the effluent perhaps as a result of some physiological 
adjustment. It would be useful to know the exact mechanism by which they tolerate the impact of the effluent. Just as with the phytoplankton biomass, the effect of the effluent on fish could be variable depending on the amount of rain, the intensity of the activity of the textile factory, the types of chemicals used, etc. While the effect of the effluent from Awassa textile factory on different age groups and different species of fish is an area of future study, our preliminary test indicates that it is very possible for the adult fish to be as vulnerable or even more sensitive than the fry.

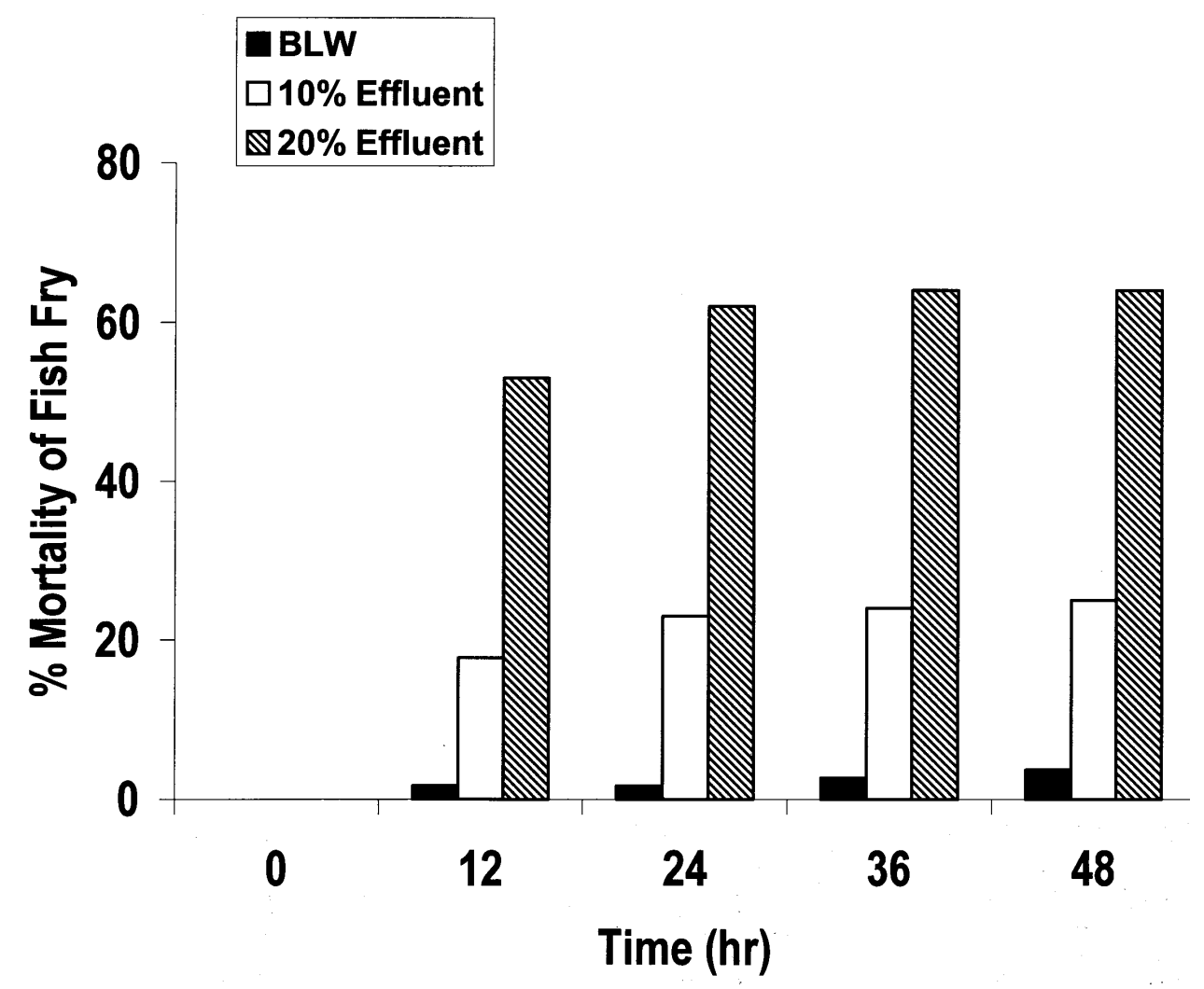

Fig. 2. Average \% mortality of fish fry in different treatments of effluent from Awassa textile factory. Values are means of results from 17 experiments.

In summary, this study has clearly revealed that the effluent from the Awassa textile factory contains relatively high concentrations of heavy metals and other trace elements of toxic nature as well as major ions and plant nutrients. The effluent treatment ponds (biological lagoons) of the factory do not seem to be removing these elements efficiently, and the effects of the "treated effluent" on phytoplankton biomass and fish fry clearly demonstrate how the lake is going to be affected when the effluent concentration in the lake reaches a noticeable level. We suspect that sewage from other sources around the lake 
(like the referral hospital that is being constructed just a few meters from the shore of Lake Awassa) will probably follow a similar fate. This calls for urgent action by all concerned bodies to see to it that the effluent from the Awassa textile factory and other possible polluters in the vicinity of the lake is handled properly. We recommend that alternate waste disposal system be established for the textile factory and its effectiveness be regularly monitored. Unless immediate measures are taken to change the present state of affairs of sewage handling around Lake Awassa, we are concerned that the lake will end up being a sewage depot rather than a healthy water body.

\section{ACKNOWLEDGEMENTS}

We thank Drs. L.J. Chapman and N.G. Nordlie of the University of Florida and Dr. A.D. Harrison of South Africa for their valuable comments on the draft manuscript. We also thank the two anonymous referees of SINET for their constructive suggestions. We are grateful to Dr. Nick J.G. Pearce of the Institute of Geography and Earth Sciences, University of Wales, U.K., for the chemical analyses of the heavy metals and other trace elements. Grant for writing this paper was provided to the corresponding author (ZGM) from the Fulbright Senior Scholarship Program through CIES, USA. The Department of Zoology, University of Florida, USA, through Dr. L.J. Chapman kindly made computer and other office facilities available to the same author.

\section{REFERENCES}

1. Chhonkar, P.K., Datta, S.P., Joshi, H.C. and Pathak, H. (2000). Impact of industrial effluents on soil health and agriculture - Indian experience: Part II - Tannery and textile industrial effluents. Journal of Scientific $\mathcal{E}$ Industrial Research. 59:446-454.

2. Demeke Kifle and Amha Belay (1990). Seasonal variation in phytoplankton primary production in relation to light and nutrients in Lake Awassa, Ethiopia. Hydrobiologia 196:217-227.

3. Elizabeth Kebede and Amha Belay (1994). Species composition and phytoplankton biomass in a tropical African lake (Lake Awassa, Ethiopia). Hydrobiologia 288: 13 - 32.

4. Forstner, U. and Witmann, G.T.W. (1983). Metal Pollution in the Aquatic Environment. $2^{\text {nd }}$ revised ed., Springer -Verlag, Berlin, p. 375.

5. Golterman, H.L., Clymo, R.S. and Ohnstad, M.A.M. (1978). Methods for the Physical and Chemical Analysis of Freshwater, $2^{\text {nd }}$ ed. Blackwell Scientific Publications, Oxford, 213 pp.

6. Pearce, F.M. (1992). The application of ICP-MS to the analysis of natural waters and an evaluation of sampling techniques. Environmental Geochemistry and Health 13:50-55. 
7. Talling, J.F. and Driver, D. (1963). Some problems in the estimation of chlorophyll-a in phytoplankton. In: Proceedings, Conference of Primary Productivity Measurement, pp. 142-146 Atomic Energy Comm., TID7633,. Marine and Freshwater, USA.

8. Wetzel, R.G. and Likens, G.E. (1979). Limnological Analysis. W.B. Saunders Co., Philadelphia, 357 pp.

9. Zerihun Desta (1997). Industrial Environmental Management: the case of Awassa Textile Factory, Ethiopia. M.Sc. Thesis. Wageningen Agricultural University (WAU), the Netherlands.

10. Zinabu Gebre-Mariam (1988). Dynamics of heterotrophic bacterioplankton in an Ethiopian rift-valley lakes (Awassa). Ph.D. Thesis, University of Waterloo, Canada.

11. Zinabu Gebre-Mariam (1994). Effects of Phytolacca Dodecandra L'Herit (Endod) on community respiration and phytoplankton biomass. SINET: Ethiop. J. Sc. 17:107-123.

12. Zinabu Gebre-Mariam (1998). Human Interactions and Water Quality in the Horn of Africa. In: Science in Africa - Emerging Water Management Problems. pp. 47-61, (Schoneboom, J., ed.) A publication of the symposium at the 1998 American Association for the Advancement of Science (AAAS), Annual Meeting, Philadelphia, Pennsylvania.

13. Zinabu Gebre-Mariam (2002). The effects of wet and dry seasons on concentrations of solutes and phytoplankton biomass in seven Ethiopian RiftValley lakes. Limnologica 32:169-179.

14. Zinabu Gebre-Mariam and Elias Dadebo (1989). Water resources and fisheries management in the Ethiopian Rift-Valley lakes. SINET: Ethiop. J. Sc. 12:95-109.

15. Zinabu Gebre-Mariam, Elizabeth Kebede and Zerihun Desta (2002). Long-term changes in the chemical and biological features of seven Ethiopian Rift Valley lakes. Hydrobiologia 477:81-91.

16. Zinabu Gebre-Mariam and Taylor, W.D. (1989). Seasonal and spatial variation in abundance, biomass and activity of heterotrophic bacterioplankton in relation to some biotic and abiotic variables in an Ethiopian riftvalley lake (Awassa). Freshwater Biology 22:355-368. 